\title{
What do Professors Want to Learn to Improve Their Teaching?
}

\author{
Jennifer A. Mather \\ University of Lethbridge
}

This paper recounts the author's experience with giving a Needs Assessment for improvement by university teachers. Subjects were from the University of Lethbridge and the 2008 Society for Teaching and Learning in Higher Education (STLHE) conference session. Teachers at the University ( $n=77)$ indicated they could spend 5-15 hours in teaching development per semester and wanted a variety of information access but favoured quick one-hour workshops. STLHE participants (n=34) were willing to attend three-hour workshops and spend more time per semester (over 20 hours) improving their teaching. Topics that both groups wanted to hear about were teaching efficiently, using student feedback, fostering critical thinking, and marking fairly. STLHE participants were more interested in fostering group work, student writing, and dealing with student disabilities and diversity, whereas the University sample cared more about preventing cheating and presenting the results of their teaching for promotion and tenure. All in all, there were many things that teachers wanted to learn.

\section{Introduction}

W hy would I do a Needs Assessment to evaluate what faculty at the University of Lethbridge wanted to learn to assist them in their teaching? I had joined the newly-minted Center for Advancement of Excellence in Teaching and Learning (CAETL) as a part-time Teaching Fellow. During the beginning of my term, the Center was evaluating what seminars, programs, and information should be offered to our faculty. In theory, teachers could just read up on how to teach well, and books such as McKeachie's (1986)
Teaching Tips (my copy is the 8th edition) and the STLHE Green Guides have put this kind of instructional assistance at everyone's fingertips. Gaining skills is not just about acquiring knowledge, as people learn better with affective input and an exchange of information. As well, some new areas such as technology (Ganske \& Hamamoto, 1984) and problembased learning (Murray \& Savin-Baden, 2000) need expert instruction for their use. Professors are, despite the fact that researchers tend to be introverts 
(Rushton, Murray, \& Paunonen, 1983), members of a social species and learn better around others.

General discussion produced casual information about what people wanted but no systematic evidence of their concerns. To fill this gap, I produced a Needs Assessment that would give the CAETL some guidance. The areas covered in the questionnaire were demographics, time faculty would devote to teaching improvement and possible scheduling, and topic areas that fell within course construction/management, evaluation strategies, technology, and other (see Appendix). In late November, the questionnaire was sent to faculty members through the web to ensure privacy, though those who felt they could give a seminar could enclose their e-mail address. The results were used to help plan our Teaching Appreciation Day in June and for a poster at the June meeting of the STLHE, where I decided to combine the STLHE conference presentation with data gathering. The poster presented the results of the survey, and people who came were requested to fill out a copy of the form, simply printed from the web. This allowed me to compare the responses of STLHE members with those of 'ordinary' university teachers.

\section{University of Lethbridge Teachers}

How did faculty want to learn about teaching? Out of a faculty number of around 450, 77 University of Lethbridge teachers answered. Many were junior (62\% with less than ten years of experience), and reflected the general belief (Schoenfeld \& Magnan, 1992) that teaching improvement was something that professors were concerned with early in their career. Even those who answered the questions were only willing to devote a modicum of time to teaching improvement $-55 \%$ said between five and 15 hours per semester. University professors lead busy lives and are aware that the major lens through which their success is viewed is research, not teaching (Schoenfeld \& Magnan, 1992). When asked what time span these instructions should take, 59\% suggested one hour 'sound bites' and only 14\% were willing to last through three hours of instruction; very few would spend a whole day improving their teaching. The form of assistance or instruction that they wanted was variable (they could have multiple choices so the numbers did not sum to $100 \%$ ), with $71 \%$ wanting web access, $54 \%$ guest lectures, 53\% discussion of teaching issues, $51 \%$ attending seminars on teaching methodology, and 52\% interested in teaching mentorships. Clearly a Teaching Development office that wished to assist them would have multiple opportunities.

So what did they want to learn about? When provided with a long list of 24 possible topics under general areas of class management, assessment, technology, and other, the respondents made some clear choices. Teaching efficiently was ranked highly; a survey of University of Lethbridge teachers showed they work over 50 hours a week and this reflects the general overwork of faculty as measured by Jacobs and Winslow (2004). Marking well and fairly and using student feedback productively also topped the list (see Table 1). Specialty areas such as long distance teaching and running a good lab were lowest, along with methodological instruction in areas such as doing away with exams and fostering online discussion for students. None of the five technology titles made the top 10; despite what we hear in the media (see Young, 2004), technology did not equate with good teaching for respondents.

\section{STLHE Participants}

Presenting the information as a poster at the 2008 STLHE conference resulted in a mix of discussion and gathering information from questionnaires. Many poster visitors were willing to complete a paper copy of the questionnaire, but paper is not the same as the web and the second set of responses was foiled for many by the necessity to turn pages to complete the questionnaire. Nevertheless, 34 STLHE participants completed the first set of questions, and 19 the topic preferences. The STLHE participants were considerably more experienced than the University sample, as $50 \%$ had more than 20 years of teaching experience. They did not believe that there was a plateau for learning about teaching and they were committed to continuing to learn. 
Table 1

Comparison of Rankings of the Top 10 Topics on Teaching Improvement ${ }^{1}$

\begin{tabular}{|l|c|c|}
\hline Topic & University of Lethbridge & STLHE Participants \\
\hline Marking well and fairly & 1 & 7 \\
\hline Teaching efficiency & 1 & 2 \\
\hline Using student feedback & 3 & 3 \\
\hline Preventing cheating & 4 & $(20)$ \\
\hline Presenting your teaching for & 5 & $(22)$ \\
tenure and promotion & 6 & 1 \\
\hline Encouraging critical thinking & 7 & 6 \\
\hline Making a teaching dossier & 8 & 7 \\
\hline Encouraging student writing & 9 & $(20)$ \\
\hline Teaching large classes well & 10 & 10 \\
\hline Encouraging class participation & $(16)$ & 3 \\
\hline Fostering group work & $(20)$ & 5 \\
\hline Dealing with diversity & $(21)$ & 7 \\
\hline Managing online discussion & & \\
\hline
\end{tabular}

How did they compare with the first sample on commitment to learning? They were willing to put in much more time to do this, with $44 \%$ indicating they would spend over 20 hours per semester. A larger proportion would attend longer sessions; 59\% wanted one hour and $47 \%$ would sit through threehour presentations, though few wanted full-day presentations. Their choice of communication methodologies was similar except that only $29 \%$ wanted web site information and $24 \%$ the newsletter. Perhaps because they were older, they were less tuned to technology. Hands-on guest lectures (47\%), discussions (65\%), methodology seminars (53\%), and mentoring $(56 \%)$ all suited them.

What were their favourite topics? There were similarities and differences with the first group. The STLHE sample rated critical thinking most important (it was only sixth for 'regular' faculty). Perhaps being just as rushed, they put teaching efficiently second (see Table 1). They were not particularly interested in student cheating, ranking it as $20^{\text {th }}$. However, they also gave the same third place ranking for using student feedback. They were interested in group work, rated a low $16^{\text {th }}$ by regular teachers, and rated online discussion fairly high at seventh.

\section{Conclusion}

What can teaching developers learn from this? First, faculty want to learn about a wide variety of topics including non-standard areas such as making a teaching dossier, learning to use PowerPoint, dealing with diverse students, and using student feedback well - all seen as part of the teaching process. In planning a set of presentations for teachers, a teaching development

\footnotetext{
${ }^{1}$ When the other group ranked a topic lower than the top 10, it is included in brackets.
} 
office could pick up on the favourites, or conduct a similar survey at its institution. Second, there's no consensus about how to learn these things; like our students, we have many different learning styles, and leaders must use all of them to communicate with teachers. Third, faculty do not have much time to devote to learning about teaching. Given the pressure of modern academic life (Jacobs \& Winslow, 2004), teachers will only attend a few and short seminars or workshops. It's certainly a challenge for any teaching development office, but one well worth undertaking. There is a world of learning out there, for us as well as our students.

\section{Acknowledgements:}

This research was carried on while the author was a Teaching Fellow in the Center for the Advancement of Excellence in Teaching and Learning, and she would like to thank Brad Reamsbottom for his assistance in construction of the questionnaire.

\section{References}

Ganske, L. \& Hamamoto, P. (1984). Response to crisis: A developer's look at the importance of needs assessment to teacher educators in the design of computer literacy training programs. ECTJ, 32, 101-113.

Jacobs, J.A. \& Winslow, S.E. (2004). Overworked faculty: Job stresses and family demands. Annals of the American Academy of Political and Social Science, 596, 104-129.

McKeachie, B. (1986). Teaching tips ( $8^{\text {th }}$ ed.). Lexington, MA: Heath.

Murray, I. \& Savin-Baden, M. (2000). Staff development in problem-based learning. Teaching in Higher Education, 5, 107-126.

Rushton, J.P., Murray, H.G., \& Paunonen, S.V. (1983). Personality, research creativity, and teaching effectiveness in university professors. Scientometrics, 5, 93-116.

Schoenfeld, A.C. \& Magnan, R. (1992). Mentor in a manual. Madison, WI: Magna.

Young, J.R. (2004). When good technology means bad teaching. The Chronicle of Higher Education, 51, A31.

\section{Biography}

Jennifer A. Mather is a Professor in the Department of Psychology at the University of Lethbridge, Alberta. Her research interests are in the behaviour of octopuses, and in fostering excellent teaching. She recently completed a one-year part-time teaching fellowship in the University's Center for Advancement of Excellence in Teaching and Learning. 


\section{Appendix \\ Teaching Development for Faculty}

The Center for the Advancement of Excellence in Teaching and Learning is planning what activities and areas of information would be helpful to the improvement of teaching by faculty. Please fill out the following questionnaire so that we can learn what areas, times and amounts of information would be suitable for you.

Faculty: A \& S Mgmt Fine Arts Education Nursing

Years of Teaching: $\quad 0-4$ $5-9$ $10-14$ 15-19 $20+$

Title: $\quad$ Professor Assoc. Prof Ass’t Prof Acad. Ass't

Lecturer Sessional

How many hours per semester could you devote to teaching improvement?

$0-4$ 5-9 $10-14$ $15-19$ $>20$

What kind of activities would assist you with your teaching?

Guest lectures Discussion groups Methodology seminars

Web site access to information Teaching mentorship Newsletter tips

What kind of scheduling would suit you best?

One-hour presentations 3-hour workshops Full-day focused workshops

Unscheduled web-based discussion Untimed information access

Pairing determined by mentoring partners 
If face-to-face is suitable for you, what times would be best for you?

Weekday noon hour Weekday late afternoons Saturday mornings

Would you prefer teaching assistance to be: Focused information Informal support

What topic areas would you like to see covered?

Course construction/management:

Making good course outlines

Fostering and evaluating class participation

Teaching large classes well

Encouraging development of writing skills

Facilitating group work

Fostering critical thinking

Developing oral presentation skills

Running a good lab

Managing cultural diversity and disability issues

Handling unreasonable students and grade appeals

Evaluation strategies

Writing good multiple choice questions

Doing away with exams

Making Web CT tests 
Marking quickly, fairly \& effectively

Cheating: avoiding it and dealing with it

Technology:

Making a good Power Point presentation

Handling multiple technologies in the big classroom

Classroom management with Web CT

Setting up online discussion groups

Doing distance courses

Other:

Making a Teaching Dossier

Presenting your teaching to the STP Committee

Doing teaching research

Using student feedback effectively

Teaching efficiently 